\title{
NORM determination in urban soils from selected cities in Chihuahua, Mexico
}

\author{
Determinación de NORM en suelos urbanos de ciudades seleccionadas \\ en Chihuahua, México
}

Luis Humberto Colmenero Sujo*, María de Lourdes Villalba** , Héctor Rubio Arias**,

María Montero Cabrera***, Humberto Silva Hidalgo**

ABSTRACT

Soil radioactivity affects the human body. This study determinates the ${ }^{238} \mathrm{U},{ }^{232} \mathrm{Th}$ and ${ }^{40} \mathrm{~K}$ activity (NORM) in 164 urban soils in 13 cities in the State of Chihuahua, Mexico. Absorbed Dose Rate and the Annual Effective Dose were also calculated. Activities were analyzed using a coaxial hyper-pure germanium detector (HPGe), Ge Model 2020, Thermo and Dewar 7500 SL (CANBERRA brand). A one-way variance analysis (ANOVA) was performed and a Tukey test was applied to identify mean differences. Activity averages were $36.8 \mathrm{~Bq} \mathrm{~kg}^{-1}$ for ${ }^{238} \mathrm{U}, 41.4 \mathrm{~Bq} \mathrm{~kg}^{-1}$ for ${ }^{232} \mathrm{Th}$ and $805.7 \mathrm{~Bq} \mathrm{~kg}^{-1}$ for ${ }^{40} \mathrm{~K}$. Calculated absorbed dose rate ranged from $36 \mathrm{nGy} \mathrm{h}^{-1}$ to $83 \mathrm{nGy} \mathrm{h}^{-1}$ while Annual Effective Dose varied from $1.02 \mathrm{mSv} \mathrm{y}^{-1}$ to $0.44 \mathrm{mSv}^{-1}$. Results suggest that some levels exceed global averages and are among the highest levels of natural radioactivity in the world.

RESUMEN

Recibido: 12 de agosto de 2015

Aceptado: 17 de marzo de 2016

\section{Keywords:}

Radioactivity; soil; Chihuahua State; dose.

Palabras clave:

Radiactividad; suelo; estado de

Chihuahua; dosis.

\section{Cómo citar:}

Colmenero Sujo, L. H., Villalba, M. de L., Rubio Arias, H., Montero Cabrera, M., \& Silva Hidalgo, H. (2016). NORM determination in urban soils from selected cities in Chihuahua, Mexico. Acta Universitaria, 26(2), 36-42. doi: 10.15174 au.2016.939

\begin{abstract}
La radiactividad del suelo afecta al cuerpo humano. Este estudio determinó la actividad del ${ }^{238} \mathrm{U},{ }^{232} \mathrm{Th}$ and ${ }^{40} \mathrm{~K}$ (NORM) en 164 suelos urbanos de trece ciudades del estado de Chihuahua, México. Se calculó la tasa de dosis absorbida y de dosis efectiva anual. Se usó un detector de germanio hiperpuro (HPGe), modelo Ge 2020, Termo y Dewar 7500 SL marca CANBERRA. Análisis de Varianza (ANOVA) y una prueba de Turkey fueron corridas para detectar las diferencias estadísticas. Los promedios de actividad fueron de $36.8 \mathrm{~Bq} \mathrm{~kg}^{-1}$ para ${ }^{238} \mathrm{U}, 41.4 \mathrm{~Bq} \mathrm{~kg}^{-1}$ para ${ }^{232} \mathrm{Th}$ y $805.7 \mathrm{~Bq} \mathrm{~kg}^{-1}$ para $40 \mathrm{~K}$. La tasa de dosis absorbida estuvo en un intervalo entre $36 \mathrm{nGy} \mathrm{h}^{-1}$ a $83 \mathrm{nGy} \mathrm{h}^{-1}$, mientras la dosis efectiva anual varió de $1.02 \mathrm{mSv} \mathrm{y}^{-1}$ a $0.44 \mathrm{mSv} \mathrm{y}^{-1}$. Los resultados muestran que algunos valores exceden los promedios mundiales y que están entre los más altos valores mundiales.
\end{abstract}

\section{INTRODUCTION}

Soil contains radioactive elements such as uranium (U) and thorium (Th) series elements, and potassium- $40\left({ }^{40} \mathrm{~K}\right)$, which are known as naturally occurring radioactive materials (NORM) (Kathren, 1998).The most important radioactive isotopes in soils are Uranium-238 $\left({ }^{238} \mathrm{U},\right)$ Thorium-232 $\left({ }^{232} \mathrm{Th}\right)$ and Potassium-40 $\left({ }^{40} \mathrm{~K}\right) .{ }^{238} \mathrm{U}$ and ${ }^{232} \mathrm{Th}$ generate many other radioactive isotopes in soils because they are the beginners of radioactive series (Bassioni, Abdulla, Morsy \& El-Faramawy, 2012; Topcuoğlu, Türer, Güngör \& Kırbaşoğlu, 2003). Potassium is the $7^{\text {th }}$ most abundant element in the earth's crust, representing approximately $2.4 \%$ of its total weight. Most of the $\mathrm{K}$ is not radioactive, only the mass 40 isotope is radioactive and it corresponds to $0.0117 \%$ of natural potassium (Jabbar et al., 2010).

The United Nations Scientific Committee on the Effects of Atomic Radiation (UNSCEAR) has published the world average activity for ${ }^{238} \mathrm{U},{ }^{232} \mathrm{Th}$ and ${ }^{40} \mathrm{~K}$ in soil: $35 \mathrm{~Bq} \mathrm{~kg}^{-1}, 25 \mathrm{~Bq} \mathrm{~kg}^{-1}$, and $370 \mathrm{~Bq} \mathrm{~kg}^{-1}$, respectively (UNSCEAR, 2000). Moreover, many countries have published their own averages (Bassioni et al., 2012; Dołhańczuk-Śródka, 2012; García-Talavera,

\footnotetext{
* Instituto Tecnológico de Chihuahua II. Avenida de las Industrias núm. 11101, Complejo Industrial Chihuahua, Chihuahua, Chihuahua, México, C.P. 31130. Phone: (52) 614 125 4078. E-mail: Icolmenero@uach.mx

** Universidad Autónoma de Chihuahua.

${ }^{* * *}$ Centro de Investigación en Materiales Avanzados, Chihuahua.
} 
Matarraz, Martínez, Salas \& Ramos, 2007; Kathren, 1998; Mehra, Singh, Sing \& Sonkawade, 2007; Topcuoğlu et al, 2003; UNSCEAR, 2000).

This world average converted into dose values of 55 nGy $^{-1}$ for Absorbed Dose Rate (D) and $0.48 \mathrm{mSv}^{-1}$ for Annual Effective Dose (AED), where the AED $\left(0.48 \mathrm{mSv}^{-1}\right)$ is about $16 \%$ of the total dose average that any human body receives from the soil (CancioPérez, 2010; UNSCEAR, 2008). In addition, the International Commission on Radiological Protection (ICRP) has recommended an annual maximum effective dose of $1 \mathrm{mSv} \mathrm{y}^{-1}$ for individuals (Jabbar et al., 2010; ICRP, 1993; Mehra et al., 2007). This is important because radioactivity can affect human health depending on the level of exposure. It is well known that bone marrow and the blood system are the most radiosensitive parts of the human body and can even be affected by low doses. Genitals are also quite sensitive to radiation. For example, people can suffer temporary sterility if they receive sufficiently high radiation, while prolonged exposure can result in permanent sterility. The lens of the eye is also highly vulnerable and radiation can cause cataracts and opacities after a certain period of exposure (Cancio-Pérez, 2010; Kathren, 1998).
Mexico uranium deposits are not commercial grade. The State of Chihuahua is considered the most important uraniferous site with 50 natural zones with about $30 \%$ of all the uranium of Mexico (Bazán-Barrón, 1978; Burciaga-Valencia et al., 2010; Colmenero-Sujo et al., 2004; Dominguez, Hernández, Arango \& Medina, 2006; Rentería-Villalobos et al., 2007; Villalba et al., 2006; Villalba, Colmenero-Sujo \& Montero, 2012).

Figure 1 shows the 12 most important uraniferous zones; some of them are near (underled uraniferous zones) large cities. There is little information about radioactivity and absorbed dose rates in Mexico. Therefore, there is no baseline for possible human risk and the potential effects of specific doses on human health have not been calculated (Bazán-Barrón, 1978; Dominguez et al., 2006).

One objective of this study was to determine the specific activity of ${ }^{238} \mathrm{U},{ }^{232} \mathrm{Th}$ series and ${ }^{40} \mathrm{~K}$ (NORM) in urban soils in 13 important large cities of Chihuahua State, Mexico. A second objective was to calculate the Dosis Range (D) and the Annual Effective Dosis (AED) that might affect Chihuahua's inhabitants. This information should be helpful for establishing preventive health measures.

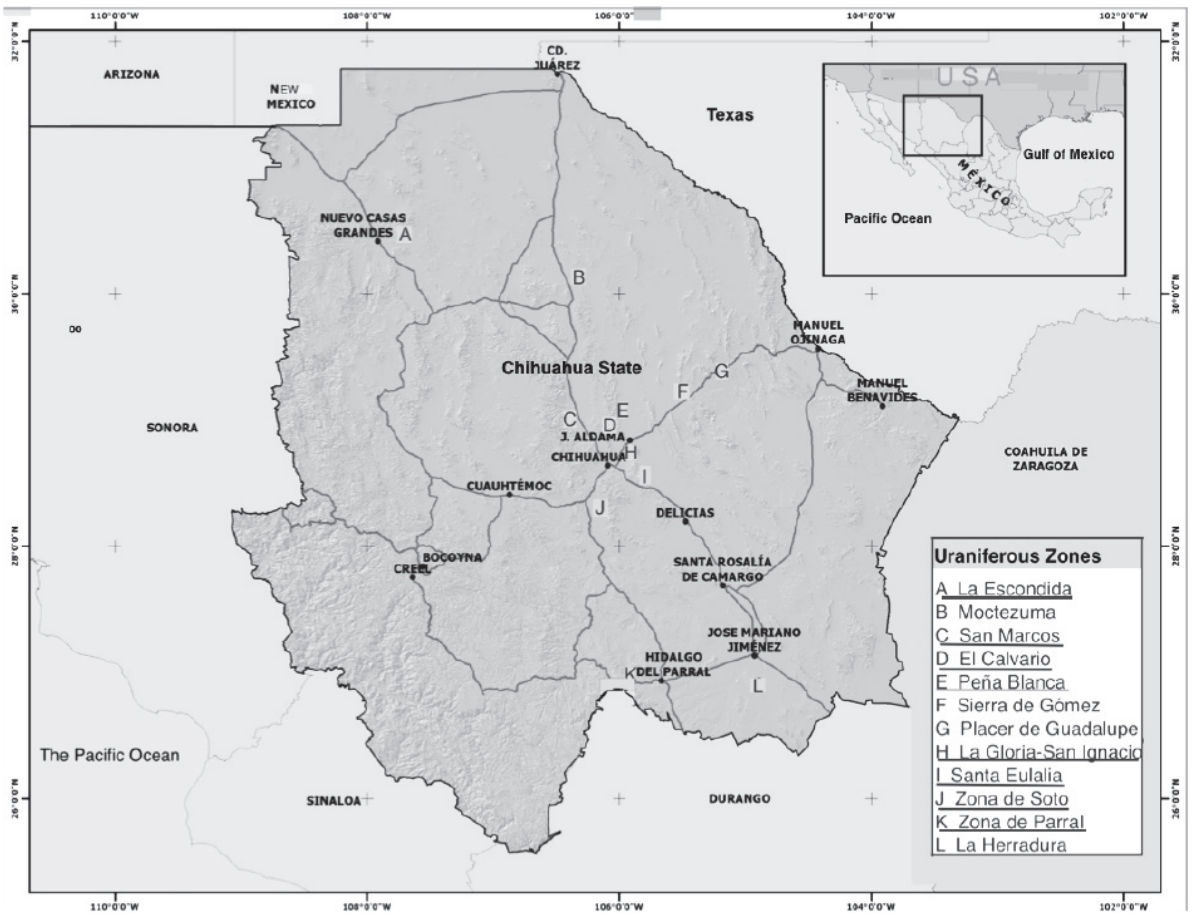

Figure 1. Main cities of Chihuahua State and its major uraniferous zones. Source: Villalba et al. (2006). 


\section{MATERIALS AND METHODS}

\section{Study area and Activity}

The State of Chihuahua is located in northern Mexico (figure 1), and has a total population of 3406465 (Instituto Nacional de Estadistica, Geografia e Informática [INEGI], 2010). Geologically, Northern Mexico is composed mainly of Mesozoic and Cenozoic sedimentary rock, as well as recent continental deposits. Natural uranium is found in Chihuahua in acidic extrusive igneous and rhyolitic and andesitic rock. Some cities are close to known uraniferous zones (Dominguez et al., 2006; INEGI, 2010).

The study was carried out in 13 cities (figure 1). A total of 164 samples were collected (table 1). The sampling employed was the one used by the Radiation Monitoring Network in Spain according to the ReViRa (for its acronym in spanish) Manual from Spain (ReViRa, 1994), and mentioned in other works (Blanco, VeraTomé \& Lozano, 2005; Colmenero-Sujo et al., 2004; Renteria-Villalobos et al., 2007). This method use a square steel structure, $50 \mathrm{~cm}$ length and $5 \mathrm{~cm}$ depth, which was placed on the ground to define the soil sample (approximately 12.51). Large stones and other objects were removed. Two liters of soil were taken to the labora- tory, where they were powdered and sieved through a $2 \mathrm{~mm}$ mesh. Finally, one liter was packed into a Marinelli beaker and sealed, and then allowed to stand for at least 4 weeks, so that ${ }^{238} \mathrm{U}$ series was able to reach radioactive secular equilibrium.

The activity of different isotopes was analyzed by a gamma spectroscopy using a coaxial hyperpure germanium detector (HPGe), Ge Model 2020, Thermo and Dewar 7500 SL (CANBERRA brand), which belongs to the Centro de Investigaciones en Materiales Avanzados (CIMAV-Chihuahua). The detector is cylindrical, $45-\mathrm{mm}$ high and $44 \mathrm{~mm}$ in diameter, with an active volume of approximately $80 \mathrm{~cm}^{3}$. The efficiency ratio of the $\mathrm{NaI}$ (TI) $3^{\prime} \times 3^{\prime}$ detector is $20 \%$. As a measure of quality control, the resolution was checked by determining the full-width at half-maximum (FWHM) for the $1332.47 \mathrm{keV}$ peak of ${ }^{60} \mathrm{Co}$, it was did daily with a source SRM4203D-65 of National Institute of Standards and Technology (NIST) whose value was $2.0 \mathrm{keV}$.

To calculate the series of ${ }^{238} \mathrm{U}$ activity, we used the lines of $351 \mathrm{keV}$ of ${ }^{214} \mathrm{~Pb}$ and $609 \mathrm{keV}$ of ${ }^{214} \mathrm{Bi}$. The series of ${ }^{232} \mathrm{Th}$ activity was obtained from lines ${ }^{238} \mathrm{keV}$ of ${ }^{212} \mathrm{~Pb}$ and $912 \mathrm{keV}$ of ${ }^{228} \mathrm{Ac}$. For the particular case of ${ }^{40} \mathrm{~K}$, we used its unique line of $1460 \mathrm{keV}$. Every sample was read for $22 \mathrm{~h}$ (Bassioni et al., 2012; BurciagaValencia et al., 2010; Mehra et al., 2007).

\begin{tabular}{|c|c|c|c|c|c|c|}
\hline City & North latitude & West longitude & High (mosl)* & Inhabitants** & Type of rocks*** & Samples \\
\hline Aldama & 2850 & 10555 & 1270 & 19378 & ird & 15 \\
\hline Bocoyna & 2751 & 10735 & 2240 & 27907 & ird & 5 \\
\hline Camargo & 2741 & 10510 & 1220 & 45852 & sll & 5 \\
\hline Creel & 2745 & 10738 & 2345 & 5026 & ird & 8 \\
\hline Cuauhtémoc & 2824 & 10652 & 2060 & 124378 & ird & 9 \\
\hline Chihuahua & 2838 & 10604 & 1440 & 671790 & ird & 30 \\
\hline Delicias & 2811 & 10528 & 1170 & 116426 & ird & 8 \\
\hline Jiménez & 2708 & 10455 & 1380 & 38323 & ird & 10 \\
\hline Juárez & 3144 & 10629 & 1140 & 1218817 & sll & 20 \\
\hline Manuel Benavides & 2906 & 10354 & 1060 & 1746 & sll & 5 \\
\hline Nuevo Casas Grandes & 3025 & 10754 & 1460 & 54390 & ird & 12 \\
\hline Ojinaga & 2934 & 10424 & 800 & 24307 & sll & 8 \\
\hline Parral & 2656 & 10540 & 1720 & 100821 & ird & 29 \\
\hline Total & & & & 2449161 & & 164 \\
\hline
\end{tabular}

${ }^{*}$ meters on the sea level; ** INEGI (2010); ${ }^{* * *}$ description Uraniferous rocks; ird = acid igneous/rhyolite/dacite; Little uraniferous rocks; sll = sandstone/ limestone/limonite Source: Author's own elaboration. 
A rigorous process of gamma ray testing was carried out using standards to calibrate the HPGe equipment with the objective of assuring consistency. These samples were analyzed, once more by other institutions such as the Centro Regional de Estudios Nucleares of the Universidad Autónoma de Zacatecas, Mexico (CREN-UAZ), and El Colegio de Física Atómica y Nuclear of the Universidad de Sevilla in Spain, corroborating that the values obtained in this study were reliable.

\section{Statistical Analysis}

A one-way Analysis of Variance (ANOVA) was performed for each variable and if statistical differences were obtained a Tukey test was used to separate means that using 0.01 as a level of significance $(\alpha=0.01)$. MINITAB 15 software was used to analyze the data (Rubio \& Jiménez, 2012).

\section{Absorbed Dose rate (D) and Annual Effective Dose (AED) calculations}

The next equations were used to calculate dose rate (d) from terrestrial radiation. It is measured at $1 \mathrm{~m}$ above the ground (Bassioni et al., 2012; DołhańczukSródka, 2012):

$\mathrm{D}\left(\mathrm{nGy} \mathrm{h}^{-1}\right)=\left(0.462 \mathrm{C}_{\mathrm{U}}+0.604 \mathrm{C}_{\mathrm{Th}}+0.0417 \mathrm{C}_{\mathrm{K}}\right)$.

Where $\mathrm{C}_{\mathrm{U}}, \mathrm{C}_{\mathrm{Th}}$ and $\mathrm{C}_{\mathrm{K}}$ represent the specific activities of each isotope in $\mathrm{Bq} \mathrm{kg}^{-1}$.

The annual effective dosis (AED) in $\mathrm{mSv}^{-1}$ was obtained:

$\mathrm{AED}=\mathrm{D}\left(\mathrm{nGy} \mathrm{h}^{-1}\right) \times 8760 \mathrm{~h} \times 0.2 \times 0.7\left(\mathrm{~Sv} \mathrm{~Gy}{ }^{-1} \mathrm{y}^{-1}\right) \times 10^{-6}$

\section{RESULTS}

Table 2 shows the mean values, standard deviation and minimum and maximum values for ${ }^{238} \mathrm{U},{ }^{232} \mathrm{Th}$ and ${ }^{40} \mathrm{~K}$ found in the soils of the 13 cities evaluated. Concentration of ${ }^{238} \mathrm{U}$ exceeded the global average (35 $\mathrm{Bq} \mathrm{kg}^{-1}$ ) in eight of the cities: Aldama, Bocoyna, Creel, Cuauhtémoc, Chihuahua, Delicias, Jiménez y Nuevo Casas Grandes. This agrees to the type of rock around these cities that have acid igneous, rhyolite and dacite rocks. The highest concentration was found in Aldama with $51.9 \mathrm{~Bq} \mathrm{~kg}^{-1}$, while the minimum value was in Juárez with $19.8 \mathrm{~Bq} \mathrm{~kg}^{-1}$. This last city is according to the type of rock it has around, sedimentary rocks like sandstone, limestone and limonite (table 2 and figure 2).
The ANOVA analysis for this isotope found statistical differences among the cities $(P<0.01)$. Besides, table 2 shows the results of the Tukey's test, which found three groups of cities. With respect to ${ }^{232} \mathrm{Th}$ ANOVA analysis found statistical differences among the cities $(P<0.01)$. It is noted that the concentration of this isotope exceeded the world average ( $35 \mathrm{~Bq} \mathrm{~kg}^{-1}$ ) in nine of the evaluated cities. The highest value was in Aldama with 61.1 Bq kg-1, while the lowest value was in Juárez with 20.0 $\mathrm{Bq} \mathrm{kg}^{-1}$ (lowest again). This is the same case of ${ }^{238} \mathrm{U}$, the difference founded between cities are the type of rocks around these cities. The mean and all values in the 13 cities were high in ${ }^{40} \mathrm{~K}$. The cities of Aldama and Nuevo Casas Grandes had the highest values with 1014.5 $\mathrm{Bq} \mathrm{kg}^{-1}$ and $1013.7 \mathrm{~Bq} \mathrm{~kg}^{-1}$, respectively, while the lowest value was in Juárez with $570.7 \mathrm{~Bq} \mathrm{~kg}^{-1}$. Moreover, the ANOVA analysis detected significant differences among cities concerning the isotope ${ }^{40} \mathrm{~K}$.

In Chihuahua's cities, in general, there are two kinds of cities according of kind of rocks, ten cities have uraniferous rocks around; Aldama, Bocoyna, Camargo, Creel, Cuauhtémoc, Chihuahua, Delicias, Jiménez, Nuevo Casas Grandes and Parral. Three cities have sedimentary rocks (no uraniferous); Juárez, Manuel Benavides and Ojinaga.

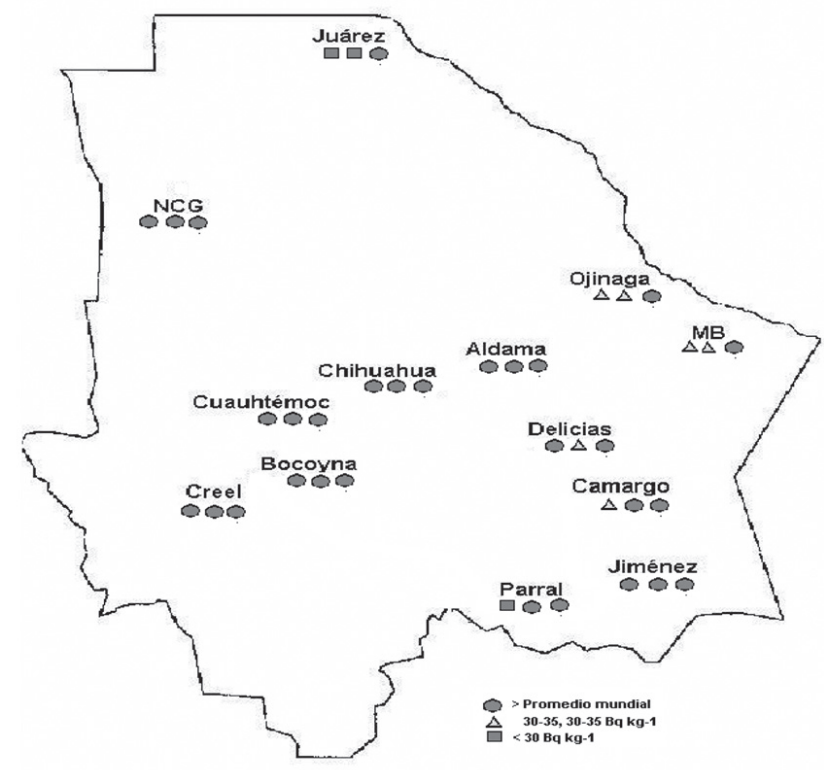

Figure 2. Specific activities of ${ }^{238} \mathrm{U},{ }^{232} \mathrm{Th}$ and ${ }^{40} \mathrm{~K}\left(\mathrm{~Bq} \mathrm{~kg}{ }^{-1}\right)$ in selected cities in Chihuahua State.

Source: Author's own elaboration. 
Table 2.

\begin{tabular}{|c|c|c|c|c|c|c|}
\hline City & ${ }^{238} \mathrm{U}$ & Min-Max & ${ }^{232} \mathrm{Th}$ & Min-Max & ${ }^{40} \mathbf{K}$ & Min-Max \\
\hline Aldama & $51.9 \pm 0.3 \mathrm{a}^{*}$ & $44.6-58.2$ & $61.1 \pm 0.5 a^{*}$ & $53.7-68.4$ & $1014.5 \pm 6.2 \mathrm{a}^{*}$ & $817.5-1106.3$ \\
\hline Bocoyna & $41.6 \pm 0.3 \mathrm{ab}$ & $34.0-47.2$ & $48.1 \pm 0.4 a b c$ & $37.9-54.7$ & $818.5 \pm 5.8 \mathrm{abcd}$ & 720.7 - 893.4 \\
\hline Camargo & $34.1 \pm 0.2 \mathrm{~b}$ & $30.7-40.1$ & $38.0 \pm 0.3 c$ & $33.1-44.6$ & $827.0 \pm 5.1 \mathrm{abcd}$ & $766.4-909.8$ \\
\hline Creel & $35.3 \pm 0.3 b$ & $29.7-55.1$ & $38.5 \pm 0.4 c$ & $33.3-55.6$ & $663.7 \pm 5.3 \mathrm{de}$ & $552.9-823.4$ \\
\hline Cuauhtémoc & $37.7 \pm 0.3 \mathrm{~b}$ & $32.0-43.3$ & $43.9 \pm 0.4 b c$ & $36.0-55.8$ & $797.6 \pm 5.5 \mathrm{bcd}$ & $571.0-972.8$ \\
\hline Chihuahua & $39.8 \pm 0.3 b$ & $28.9-54.6$ & $55.2 \pm 0.4 \mathrm{ab}$ & $23.5-102$ & $916.6 \pm 6.0 \mathrm{ab}$ & $653.1-1179.2$ \\
\hline Delicias & $36.5 \pm 0.3 b$ & $31.3-43.6$ & $33.4 \pm 0.4 c$ & $28.5-38.2$ & $772.0 \pm 5.8 \mathrm{bcde}$ & $685.6-848.5$ \\
\hline Jiménez & $40.4 \pm 0.3 b$ & $38.1-45.9$ & $42.3 \pm 0.4 c$ & $38.2-49.5$ & $930.5 \pm 6.1 \mathrm{ab}$ & $842.5-1002.8$ \\
\hline Juárez & $19.8 \pm 0.2 \mathrm{c}$ & $18.5-23.0$ & $20.0 \pm 0.3 d$ & $15.3-25.4$ & $570.7 \pm 2.9 \mathrm{e}$ & $512.5-631.4$ \\
\hline Manuel Benavides & $34.8 \pm 0.2 b$ & $27.3-41.1$ & $32.9 \pm 0.3 \mathrm{~cd}$ & $20.0-39.4$ & $601.7 \pm 4.3 \mathrm{de}$ & $414.4-828.9$ \\
\hline Nuevo Casas Grandes & $41.1 \pm 0.3 \mathrm{~b}$ & $37.7-44.9$ & $55.9 \pm 0.5 \mathrm{ab}$ & $48.9-63.6$ & $1013.7 \pm 6.9 a$ & $954.0-1069.1$ \\
\hline Ojinaga & $31.8 \pm 0.3 \mathrm{~b}$ & $27.6-34.1$ & $32.0 \pm 0.4 \mathrm{~cd}$ & $27.2-36.1$ & $688.3 \pm 4.7 \mathrm{cde}$ & $577.9-742.2$ \\
\hline Parral & $34.8 \pm 0.3 b$ & $18.3-63.3$ & $36.6 \pm 0.4 c$ & $10.3-63.1$ & $859.0 \pm 5.9 \mathrm{abc}$ & $534.2-1796.8$ \\
\hline Mean & $36.8 \pm 0.3$ & & $41.4 \pm 0.4$ & & $805.7 \pm 5.4$ & \\
\hline
\end{tabular}

* Means in columns that do not share a letter are statistically different.

Source: Author's own elaboration.

\section{Absorbed Dose Rate and Annual Effective Dose}

The values for $\mathrm{D}$ determined range from $36 \mathrm{nGy} \mathrm{h}^{-1}$ to $83 \mathrm{nGy} \mathrm{h}^{-1}$. Nine of the 13 cities had $\mathrm{D}$ values equal to or higher than the global average, which is $55 \mathrm{nGy} \mathrm{h}^{-1}$ (UNSCEAR, 2008). The average D for Chihuahua State was 60.6 nGy h$^{-1}$.

Figure 3 shows the AED calculated for NORM for each sampled city. Twelve of the thirteen cities had levels equal to or higher than the world average $\left(0.48 \mathrm{mSv}^{-1}\right)$ (UNSCEAR, 2008). Ciudad Aldama had the highest value with $1.02 \mathrm{mSv} \mathrm{C}$ while Ciudad Juarez the lowest value with $0.44 \mathrm{mSv}^{-1}$, lower than the world average. The average AED for Chihuahua State was $0.74 \mathrm{mSv} \mathrm{y}^{-1}$.

\section{DISCUSSION}

The three NORM means were greater than the value by United Nations Scientific Committee of the Effects of Atomic Radiation (UNSCEAR) published (UNSCEAR, 2000). Aldama had the highest values and Ciudad Juarez the lowest values. According to Jabbar et al. (2010) the abundance of potassium in the soil depends on its characteristics; artificially fertilized soil has high amounts of potassium because of its additive property from potassium in the fertilizers.
It is important to point out that Ciudad Aldama had the highest values of the three natural isotopes: $67 \%$ higher than the world average for ${ }^{238} \mathrm{U}, 48 \%$ higher for ${ }^{232} \mathrm{Th}$ and $174 \%$ higher for ${ }^{40} \mathrm{~K}$. Comparing the averages in Chihuahua to those in other countries we can see that it has higher NORM levels than Luxemburg, Hungary, Japan, Bangladesh, China, Romania and Spain, and similar values to regions like Punjab, India (Dołhańczuk-Śródka, 2012; Jabbar et al., 2010; Mehra et al., 2007). Chihuahua city and Chihuahua State have been mentioned in others papers for its high radioactive levels (Colmenero-Sujo et al., 2004; Colmenero-Sujo \& Villalba, 2010; Villalba et al., 2012).

In Absorbed dose rate (D), it is important to point out that the value obtained is higher than the world average and higher than levels reported in the United States, Switzerland, Luxemburg, Japan, Romania, Taiwan and others countries (Dołhańczuk-Sródka, 2012; Jabbar et al., 2010; Mehra et al., 2007; Quindos, Fernández, Rodenas, Gómez-Arozamena \& Arteche, 2004; Tzortzis, Tsertos, Christofides \& Chistodoclides, 2003). Similar studies carried out in other regions of Mexico have reported lower values than those in Chihuahua. For example, the average D level in the State of Zacatecas is $44.9 \mathrm{nGy} \mathrm{h}^{-1}$ (Mireles et al., 2003).

The Comision Nacional de Seguridad Nuclear y Salvaguardias (CNSNS, 2012) of Mexico reported results in some regions of Mexico, however, the CNSNS did not refer to studies in Chihuahua State. 


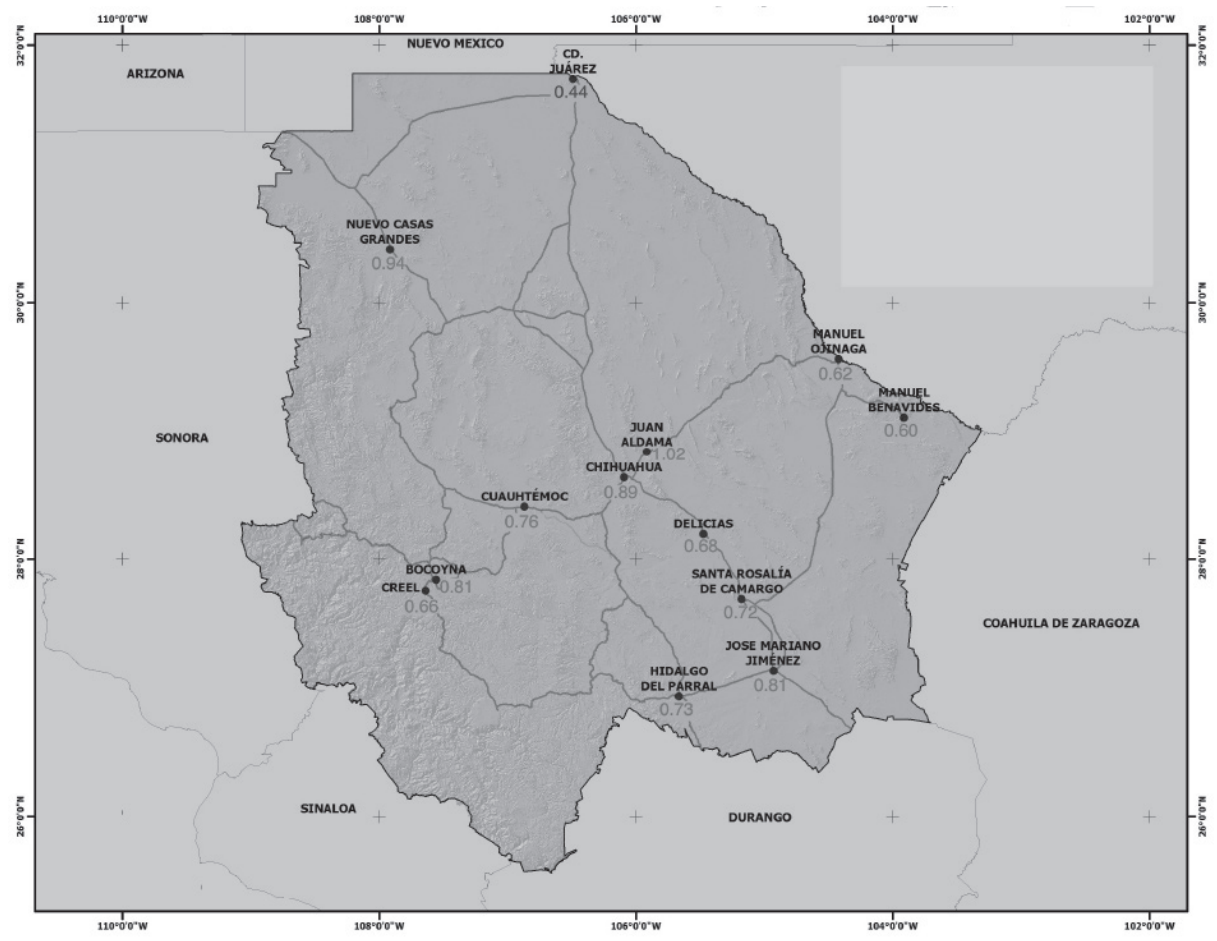

Figure 3. NORM doses in urban soils of selected cities of Chihuahua State $\left(m S v y^{-1}\right)$.

Source: Author's own elaboration.

Some studies like Punjab, India, reported by Mehra et al. (2007) indicated that AED ranges from $0.28 \mathrm{mSv} \mathrm{y}^{-1}$ to $0.64 \mathrm{mSv}^{-1}$, In some papers report that Pakistan and Czech Republic average values of $0.43 \mathrm{mSv}^{-1}$ and $0.44 \mathrm{mSv} \mathrm{y}^{-1}$ respectively have been reported (Dołhań czuk-Śródka, 2012; Jabbar et al., 2010).

The ICRP (1993) should declare to Ciudad Aldama a radioactive risk zone according at this work and others.

\section{CONCLUSIONS}

Results reported here represent the radioactivity from the geology of selected cities in the Chihuahua State. Eight cities in Chihuahua had higher levels of natural radionuclides than the world average. Nine cities had dose rates equal to or higher than national and international averages, while 12 cities had annual effective doses equal to or higher than national and international averages. These cities have $72 \%$ of the inhabitants of Chihuahua State.

We recommend that the Mexican Nuclear Safety Agency consider adopting the averages reported here as they are the results of a rigorous scientific study.

\section{REFERENCES}

Bassioni, G., Abdulla, F., Morsy, Z., \& El-Faramawy, N. (2012). Evaluation of Naturally Occurring Radioactive Materials (NORMs) in Inorganic and Organic Oilfield Scales from the Middle East. Archives of environmental contamination and toxicology, 62(3), 361-368.

Bazán-Barrón, S. (1978). Génesis y depositación de los yacimientos de molibdeno y uranio, en el distrito de Villa Aldama, Chihuahua. Boletín de la Sociedad Geológica Mexicana, 39(2), 25-33.

Burciaga-Valencia, D. C., Reyes-Cortes, M., Reyes-Rojas, A., Rentería-Villalobos, M., Esparza-Ponce, H., Fuentes-Cobas, L., Fuentes-Montero, L., SilvaSaenz, M., Herrera-Peraza, E., Muñoz, A., \& Montero-Cabrera, M. E. (2010). Characterization of uranium minerals from Chihuahua using synchrotron radiation. Revista Mexicana de Física, 56(1), 75-81.

Blanco, P., Vera-Tomé, F., \& Lozano, J. C. (2005). Fractionation of natural radionuclides in soils from a uranium mineralized area in the south-west of Spain. Journal of environmental radioactivity, 79(3), 315-330.

Cancio-Pérez, D. (2010). Impacto radiológico de las fuentes naturales y artificiales de la radiación. El informe UNSCEAR 2008. Nucleus, (48), 3-9.

Comisión Nacional de Seguridad Nuclear y Salvaguardias (CNSNS) (2012). Valores de la exposición a la radiación natural medidos en diferentes puntos de la República Mexicana. México: CNSNS. Retrieved from 5 june 2015 from www.cnsns.gob.mx/seguridad_nuclear/expo_radiacion.php 
Colmenero-Sujo, L., Montero Cabrera, M. E., Villalba, L., Rentería-Villalobos, M., Torres-Moye, E., García-León, M., García-Tenorio, R., Mireles-García, F., Herrera-Peraza, E. F., \& Sánchez-Aroche, D. (2004). Uranium-238 and thorium-232 series concentrations in soil, radon-222 indoor and drinking water concentrations and dose assessment in the city of Aldama, Chihuahua, Mexico. Journal of environmental radioactivity, 77(2), 205-219.

Colmenero-Sujo, L., \& Villalba, L. (2010). Presencia de radón en casas habitación del estado de Chihuahua. TecnoCiencia-Chihuahua, 4(3), 122-125.

Dołhańczuk-Śródka, A. (2012). Estimation of external gamma radiation dose in the area of Bory Stobrawskie forests (PL). Environmental monitoring and assessment, 184(9), 5773-5779.

Domínguez, I., Hernández, N. A., Arango, A., \& Medina, J. (2006). Yacimientos de uranio en México. Boletín de Mineralogía, (17), 45-54.

García-Talavera, M., Matarraz, J. L. M., Martínez, M., Salas, R., \& Ramos, L. M. (2007). Exposición de la población española a la radiación ionizante de origen natural. Seguridad nuclear: Revista del CSN, (43), 40-46.

International Commission on Radiological Protection (ICRP) (1993). ICRP publication 65 (vol. 2, p. 23). Annals of the ICRP. Oxford: Pergamon Press.

Instituto Nacional de Estadística, Geografía e Informática (INEGI) (2010). Retrieved june 2015 from www.inegi.gob.mx

Jabbar, A., Arshed, W., Bhatti, A. S., Ahmad, S. S., Akhter, P., Rehman S. U., \& Anjum, M. I. (2010). Measurement of soil radioactivity levels and radiation hazard assessment in southern Rechna interfluvial region, Pakistan. Environmental monitoring and assessment, 169(1-4), 429-438.

Kathren, R. L. (1998). NORM Sources and their origins. Applied radiation and isotopes, 49(3), 149-168.

Mehra, R., Singh, S., Sing, K., \& Sonkawade, R. (2007). ${ }^{226} \mathrm{Ra},{ }^{232} \mathrm{Th}$ and ${ }^{40} \mathrm{~K}$ analysis in soils sample from areas of Malwa region, Punjab, India using gamma ray spectrometry. Environmental monitoring and assessment, 134(1-3), 333-342.

Mireles, F., Dávila, J. I., Quirino, L. L., Lugo, J. F., Pinedo, J. L., \& Ríos, C. (2003). Natural soil gamma radioactivity levels and resultant population dose in the cities of Zacatecas and Guadalupe, Zacatecas, Mexico. Health physics, 84(3), 368-372.

Quindos, L. S., Fernández, P. L., Rodenas, C., Gómez-Arozamena, J., \& Arteche J. (2004). Conversion factors for external gamma dose derived from natura radionuclides in soils. Journal of environmental radioactivity, 71(2), 139-145.
Rentería-Villalobos, M., Montero-Cabrera, M. E., Reyes-Cortés, M., HerreraPeraza, E. F., Rodríguez-Pineda, A., Manjón-Collado, G., García-Tenorio, R., Crespo, T., \& Valenzuela-Hernández, M. (2007). Characterization of source rocks and groundwater radioactivity at the Chihuahua Valley. Revista Mexicana de Física, 53(3), 16-22.

Red de Vigilancia Radiológica Ambiental Nacional para España (ReViRa) (1994). Procedimientos de muestreo. Consejo de Seguridad Nuclear. España: ReViRa.

Rubio, H., \& Jiménez, J.A. (2012). Estadística experimental con apoyo de Minitab. México: Universidad Autónoma de Chihuahua.

Topcuoğlu, S., Türer, A., Güngör, N., \& Kırbaşoğlu, C. (2003). Monitoring of anthropogenic and natural radionuclides and gamma absorbed dose rates in eastern Anatolia. Journal of radioanalytical and nuclear chemistry, 258(3), 547-550.

Tzortzis, M., Tsertos, H., Christofides, S., \& Chistodoclides, G. (2003). Gammaray measurements of naturally occurring radioactive samples from Cyprus characteristic geological rocks. Radiation Measurements, 37(3), 221-229.

United Nations Scientific Committee on the Effects of Atomic Radiation (UNSCEAR) (2000). Report to the General Assemby. Annex B: Exposures from natural radiation sources, B, 123.

United Nations Scientific Committee on the Effects of Atomic Radiation (UNSCEAR) (2008). Report to the General Assemby. Sources and effects of ionizing radiation, 1, 23, 234.

Villalba, L., Montero-Cabrera, M. E., Manjón-Collado, G., Colmenero-Sujo, L., Rentería-Villalobos, M., Cano-Jiménez, A., Rodríguez-Pineda, A., DávilaRangel, I., Quirino-Torres, L., \& Herrera-Peraza, E. F. (2006). Natural radioactivity in ground water and estimates of committed effective dose due to water ingestion in the state of Chihuahua (Mexico). Radiation protection dosimetry, 121(2), 148-157.

Villalba, L., Colmenero-Sujo, L., \& Montero, M (2012). Análisis y dosimetría de radionúclidos en agua en el estado de Chihuahua. Madrid: Académica Española. 